\title{
HLA haplotypes associated with hemochromatosis mutations in the Spanish population
}

\author{
Arantza Pacho, Esther Mancebo, Manuel J del Rey, Maria J Castro, \\ Desamparados Oliver, Miguel García-Berciano, Luis González and \\ Pablo Morales*
}

Address: Immunology. Hospital Universitario "12 de Octubre". Carretera de Andalucia. 28041. Madrid, Spain

Email: Arantza Pacho - arantzapacho@yahoo.es; Esther Mancebo - esmasi77@hotmail.com; Manuel J del Rey - ermanu@yahoo.es; Maria J Castro - mjcp1965@yahoo.es; Desamparados Oliver - amparo_oliver@hotmail.com; Miguel García-

Berciano - MIGABER@telefonica.net; Luis González - luisitogp2003@yahoo.es; Pablo Morales* - pmorales@h12o.es

* Corresponding author

Published: 21 October 2004

BMC Medical Genetics 2004, 5:25 doi:10.1 186/147/-2350-5-25
Received: 12 May 2004

Accepted: 21 October 2004

This article is available from: http://www.biomedcentral.com/l47I-2350/5/25

(C) 2004 Pacho et al; licensee BioMed Central Ltd.

This is an open-access article distributed under the terms of the Creative Commons Attribution License (http://creativecommons.org/licenses/by/2.0), which permits unrestricted use, distribution, and reproduction in any medium, provided the original work is properly cited.

\begin{abstract}
Background: The present study is an analysis of the frequencies of HLA-A and $-B$ antigens and HLA haplotypes in two groups of individuals homozygous for the two main HFE mutations (C282Y and H63D) and a group heterozygous for the S65C mutation.
\end{abstract}

Methods: The study population includes: I 123 healthy individuals, 100 homozygous for the C282Y mutation, 138 homozygous for the H63D mutation and 17 heterozygous for the $\mathrm{S} 65 \mathrm{C}$ mutation. HFE and HLA alleles were detected using DNA-based and microlymphocytotoxicity techniques respectively.

Results: An expected significant association between $\mathrm{C} 282 \mathrm{Y}$ and the HLA-A3/B7 haplotype was found, but other HLA haplotypes carrying the -A3 antigen were found: HLA-A3/B62 and HLA-A3/ B44. Also, a significant association between H63D mutation and HLA-A29/B44 haplotype was found, and again other HLA haplotypes carrying the HLA-A29 antigen were also found: HLA-A29/ BI4 and HLA-A29/B62. In addition, the S65C mutation seems to be associated with a HLA haplotype carrying the HLA-A26 antigen.

Conclusion: These findings clearly suggest that HLA-A3/B7 and HLA-A29/B44 are the ancestral haplotypes from which the C282Y and H63D mutations originated, respectively. The frequencies of these mutations in different populations, their geographical distribution, and the degree of the statistical association to the ancestral haplotypes, suggest that the H63D mutation must have occurred earlier than the $\mathrm{C} 282 \mathrm{Y}$ mutation.

\section{Background}

Hereditary hemochromatosis ( $\mathrm{HH}$ ) is an autosomal recessive disease common in northern European populations. $\mathrm{HH}$ is characterized by increased iron absorption and dep- osition in the liver, pancreas, heart, joints and pituitary gland. Without treatment, death may occur from cirrhosis, primary liver cancer, diabetes or cardiomyopathy. In 1996, the HH gene (HFE) was cloned and located on the 
short arm of chromosome 6 (6p21.3) [1], 4 megabases (Mb) telomeric to the major histocompatibility complex (MHC). A single point mutation $845 \mathrm{G}>\mathrm{A}$ (exon 4), changing cysteine at position 282 to tyrosine (C282Y) is identified in 85 to $100 \%$ of patients with $\mathrm{HH}$ in populations of northern European descent, but it is found in only $60 \%$ of cases from Mediterranean populations [2]. Two other mutations, $187 \mathrm{C}>\mathrm{G}$ (exon 2), a histidine to aspartate change at amino acid 63 (H63D) and $193 \mathrm{~A}>\mathrm{T}$ (exon 2 ), a serine to cysteine change at amino acid 65 (S65C) appear to be associated with milder forms of $\mathrm{HH}$ and may increase risk of disease in persons heterozygous for $\mathrm{C} 282 \mathrm{Y}$ mutation $[3,4]$.

C282Y lies within a Celtic ancestral haplotype which includes the human MHC (HLA) haplotype HLA-A3/B7 [5]. The HLA-A3/B7 haplotype was reported in $\mathrm{HH}$ patients in many European and populations of European descent [5-8] but HLA-A3/B14, HLA-A3/B35 and others were also reported [9-11]. The predominance of the HLAA3 associated haplotypes on hemochromatosis chromosomes, and the pattern of their distribution in the world, led Simon et al [5] to propose the founder hypothesis, postulating that the hemochromatosis mutation was a rare event that occurred once on a particular chromosome which was subsequently modified by recombinations involving both HLA-B and HLA-A alleles and population migrations, producing the varied haplotype associations that were described.

In contrast, the H63D substitution is not restricted to European populations: allele frequencies greater than 5\% are found in countries bordering the Mediterranean, in the Middle East, and in the Indian subcontinent. H63D seems to be associated with HLA-A29 and HLA-B44 $[3,12]$.

A few studies have been performed on the distribution of the S65C mutation in Europe and other countries. In 1999, Barton et al [13] identified the S65C mutation in Alabama hemochromatosis probands and found that this mutation was linked to a haplotype characterized by HLAA32; and recently, Couto et al [14] found that this mutation is in linkage disequilibrium with the HLA-A29/B44 haplotype.

The aim of this study is to find the HLA antigens and haplotypes associated with the three main mutations in the HFE gene in a sample of the Spanish population.

\section{Methods \\ Individuals}

A total of 100 unrelated individuals homozygous for the C282Y mutation, 138 unrelated individuals homozygous for the H63D mutation and 17 individuals heterozygous for the S65C mutation were selected for this study. These were subjects in whom HFE genotyping has been previously performed on a medical care basis because of a presumptive diagnosis of hemochromatosis. In addition, 1113 unrelated, apparently healthy subjects were used as controls for the study. In addition, HLA typing was performed in 230 individuals whom HFE genotyping was negative for the three mutations.

\section{HLA-A and -B typing}

HLA-class I typing was performed on freshly collected venous blood samples by the standard complementdependent microlymphocytotoxicity assay using commercially available alloantisera.

\section{DNA extraction and HFE amplification}

Genomic DNA from whole blood samples was extracted by standard protocols. Polymerase chain reaction (PCR) with the pair of primers HEMEx2-5' (5'-CTT TGG GCT ACG TGG ATG ACC) and HEMEx2-3' (5'-CTG GCT TGA AAT TCT ACT GGA AAC C) was used to amplify exon 2 of the HFE gene. To amplify exon 4 , a second set of oligonucleotides was used: HEMEx4-5' (5'-GGT GTC GGG CCT TGA ACT ACT ACC) and HEMEx4-3' (5'-A CAT ACC CCA GAT CAC AAT GAG G).

The following conditions were used for the PCR reactions: five minutes denaturation at $94^{\circ} \mathrm{C}, 40$ cycles of $15 \mathrm{sec}$ onds denaturation at $95^{\circ} \mathrm{C}, 15$ seconds annealing at $57^{\circ} \mathrm{C}$ and 30 seconds extension at $72^{\circ} \mathrm{C}$. PCR products coming from exons 2 and 4 were 101 and 228 base pairs (bp), respectively.

\section{Digestion with mutation-specific restriction endonuclease} Following the PCR amplifications, aliquots $(17 \mu \mathrm{l})$ of the reaction mixture were digested with the restriction endonucleases Bcl I (exon 2), Hinf I (exon 2) and Rsa I (exon 4) for 3 hours following the protocol recommended by the manufacturer (Promega, Madison, WI). The H63D mutation destroys the $\mathrm{Bcl}$ I site in the $101 \mathrm{bp}$ PCR product, so while normal DNA is cut into two fragments of 38 and 63 bp, the mutated DNA is not cut. The S65C mutation destroys the Hinf I site in the 101 bp PCR product, so while normal DNA is cut into two fragments of 47 and 54 bp, the mutated DNA is not cut. The C282Y mutation creates a new Rsa I site, the 228 bp DNA product digested with this enzyme is cut into two fragments of 145 and 83 bp in the normal allele, while in the mutated DNA three fragments of 145, 29 and 54 bp are generated after digestion. The digested products were size resolved in $10 \%$ acrylamide gel and detected by staining with ethidium bromide. 


\section{Statistical analysis}

Allele and haplotype frequencies were estimated using Arlequin V2.0 software [15]. The haplotype frequencies were computed using the Expectation-Maximization algorithm [16]; this procedure is an interactive process aimed at obtaining maximum-likelihood estimates of haplotype frequencies from multi-locus genotype data when the gametic phase is unknown. The existence of association between HFE mutations and HLA-A and -B alleles and haplotypes was calculated by $2 \times 2$ comparison tables and $p$ values were corrected according to the number of alleles or haplotypes compared [17] and using Yates corrected $\mathrm{Chi}^{2}$ and Fisher's tests. Odds ratios were calculated as previously described [18].

\section{Results}

The allele frequencies of the HLA-A and -B antigens found in the $\mathrm{C} 282 \mathrm{Y}$ carriers group, in comparison with the frequencies in the control population are listed in Table 1. As expected, significant associations were found for HLA-A3 and -B7, but HLA-B62 also shows significant association. The association of HLA-A3 is stronger than that of HLA-B7 or -B62. The frequencies of the HLA-A/B haplotypes in the homozygous group in comparison with the haplotype frequencies in the control population are listed in Table 2. Three haplotypes are significantly associated with the C282Y mutation: HLA-A3/B7, HLA-A3/B62 and HLA-A3/ B44.

Table 2: Frequencies of HLA-A/B haplotypes in the two groups homozygous for H63D and C282Y in comparison with the control group.

\begin{tabular}{|c|c|c|c|c|c|c|c|}
\hline HAPLOTYPE & $\begin{array}{l}\text { H63D HAPLOTYPES } \\
\text { Freq }(n=276)\end{array}$ & $\mathrm{P}$ & OR & $\begin{array}{l}\text { C282Y HAPLOTYPES } \\
\text { Freq }(\mathrm{n}=200)\end{array}$ & $P$ & OR & $\begin{array}{c}\text { CONTROLS } \\
\text { Freq }(n=2226)\end{array}$ \\
\hline $\mathrm{Al} / \mathrm{B} 8$ & 0.02513 & N.S. & & 0.01500 & N.S. & & 0.0246 \\
\hline $\mathrm{A} 2 / \mathrm{B} 7$ & 0.03612 & N.S. & & 0.02859 & N.S. & & 0.0239 \\
\hline A2/B44 & 0.08254 & N.S. & & 0.04037 & N.S. & & 0.0443 \\
\hline $\mathrm{A} 2 / \mathrm{B} 5 \mathrm{I}$ & 0.04839 & N.S. & & 0.00000 & & & 0.0404 \\
\hline A2/B35 & 0.01545 & N.S. & & 0.03543 & N.S. & & 0.0258 \\
\hline $\mathrm{A} 3 / \mathrm{B} \mid 4$ & 0.00000 & & & 0.00000 & & & 0.0005 \\
\hline A3/B7 & 0.00725 & N.S. & & 0.20275 & $<10^{-7}$ & 7.29 & 0.0343 \\
\hline A3/B62 & 0.00000 & & & 0.03379 & $10-5$ & 16.11 & 0.0024 \\
\hline A3/B44 & 0.00409 & N.S. & & 0.08989 & $<10$ & 12.13 & 0.0079 \\
\hline All/B27 & 0.01812 & N.S. & & 0.00000 & & & 0.0064 \\
\hline All/B35 & 0.00362 & N.S. & & 0.00862 & N.S. & & 0.0204 \\
\hline A24/B35 & 0.00794 & N.S. & & 0.01478 & N.S. & & 0.0233 \\
\hline A29/B44 & 0.13261 & $<10-7$ & 3.93 & 0.02999 & N.S. & & 0.0378 \\
\hline A29/B I 4 & 0.01449 & $<0.01$ & 32.7 & 0.00000 & & & 0.0005 \\
\hline A29/B 62 & 0.01591 & $<0.01$ & 32.7 & 0.00000 & & & 0.0005 \\
\hline $\mathrm{A} 30 / \mathrm{B} 18$ & 0.01087 & N.S. & & 0.00000 & & & 0.0278 \\
\hline $\mathrm{A} 33 / \mathrm{B} \mid 4$ & 0.00000 & & & 0.00500 & N.S. & & 0.0121 \\
\hline
\end{tabular}

Freq: Frequency n: Total number of haplotypes in each group OR: Odds ratio p: Significance level N.S.: Not significant

Table I: Allele frequencies of HLA-A and HLA-B antigens in the C282Y homozygous group in comparison with the control group.

\begin{tabular}{|c|c|c|c|c|c|c|c|c|c|}
\hline \multirow[b]{2}{*}{ HLA } & \multicolumn{3}{|c|}{ C282Y HOMOZYGOTES } & \multirow{2}{*}{$\begin{array}{c}\text { CONTROLS } \\
\text { Freq }(n=2226)\end{array}$} & \multirow[b]{2}{*}{ HLA } & \multicolumn{3}{|c|}{ C282Y HOMOZYGOTES } & \multirow{2}{*}{$\begin{array}{c}\text { CONTROLS } \\
\text { Freq }(n=2226)\end{array}$} \\
\hline & Freq $(n=200)$ & OR & $\mathrm{P}$ & & & Freq $(n=200)$ & OR & $\mathrm{P}$ & \\
\hline Al & 0.070 & 0.69 & N.S. & 0.097 & B8 & 0.035 & 0.81 & N.S. & 0.044 \\
\hline \multirow[t]{2}{*}{ A3 } & 0.425 & 6.23 & $<10-7$ & 0.106 & B7 & 0.260 & 3.67 & $<10-7$ & 0.089 \\
\hline & & & & & B62 & 0.075 & 2.74 & 0.030 & 0.028 \\
\hline $\mathrm{A} 29$ & 0.035 & 0.54 & N.S. & 0.062 & B44 & 0.170 & 1.19 & N.S. & 0.146 \\
\hline $\mathrm{A} 30$ & 0.010 & 0.16 & 0.093 & 0.060 & $\mathrm{~B} 18$ & 0.015 & 0.27 & 0.120 & 0.088 \\
\hline $\mathrm{A} 2$ & 0.195 & 0.67 & N.S. & 0.264 & B35 & 0.095 & 0.77 & N.S. & 0.119 \\
\hline All & 0.060 & 0.75 & N.S. & 0.078 & B5I & 0.055 & 0.60 & N.S. & 0.088 \\
\hline $\mathrm{A} 26$ & 0.020 & 0.42 & N.S. & 0.046 & B49 & 0.025 & 0.67 & N.S. & 0.036 \\
\hline A28 & 0.025 & 0.59 & N.S. & $0.04 I$ & B60 & 0.015 & 0.42 & N.S. & 0.035 \\
\hline $\mathrm{A} 32$ & 0.020 & 0.57 & N.S. & 0.034 & B।4 & 0.010 & 0.28 & N.S. & 0.035 \\
\hline $\mathrm{A} 23$ & 0.030 & 0.95 & N.S. & 0.031 & B38 & 0.010 & 0.33 & N.S. & 0.029 \\
\hline A33 & 0.010 & 0.36 & N.S. & 0.027 & B27 & 0.025 & 0.88 & N.S. & 0.028 \\
\hline $\mathrm{A} 25$ & 0.020 & 0.97 & N.S. & 0.020 & B50 & 0.005 & 0.21 & N.S. & 0.023 \\
\hline A3I & 0.025 & 1.56 & N.S. & 0.016 & B 65 & 0.015 & 0.64 & N.S. & 0.023 \\
\hline
\end{tabular}

Freq: Frequency n: Total number of alleles in each group OR: Odds ratio p: Significance level N.S.: Not significant 
Table 3: Allele frequencies of HLA-A and HLA-B antigens in the H63D homozygous group in comparison with the control group.

\begin{tabular}{|c|c|c|c|c|c|c|c|c|c|}
\hline \multirow[b]{2}{*}{ HLA } & \multicolumn{3}{|c|}{ H63D HOMOZYGOTES } & \multirow{2}{*}{$\begin{array}{c}\text { CONTROLS } \\
\text { Freq }(n=2226)\end{array}$} & \multirow[b]{2}{*}{ HLA } & \multicolumn{3}{|c|}{ H63D HOMOZYGOTES } & \multirow{2}{*}{$\begin{array}{l}\text { CONTROLS } \\
\text { Freq }(n=2226)\end{array}$} \\
\hline & Freq $(n=276)$ & OR & $P$ & & & Freq $(n=276)$ & OR & $P$ & \\
\hline Al & 0.061 & 0.60 & N.S. & 0.097 & B8 & 0.050 & 1.14 & N.S. & 0.044 \\
\hline \multirow[t]{2}{*}{$\mathrm{A} 3$} & 0.086 & 0.80 & N.S. & 0.106 & B7 & 0.068 & 0.75 & N.S. & 0.089 \\
\hline & & & & & B62 & 0.028 & 1.00 & N.S. & 0.028 \\
\hline A29 & 0.199 & 3.65 & $<10^{-7}$ & 0.062 & B44 & 0.264 & 2.10 & $2.10^{-5}$ & 0.146 \\
\hline $\mathrm{A} 30$ & 0.036 & 0.58 & N.S. & 0.060 & $\mathrm{~B} 18$ & 0.086 & 0.98 & N.S. & 0.088 \\
\hline $\mathrm{A} 2$ & 0.286 & 1.12 & N.S. & 0.264 & B35 & 0.076 & 0.60 & N.S. & 0.119 \\
\hline All & 0.036 & 0.44 & N.S. & 0.078 & B5I & 0.097 & 1.12 & N.S. & 0.088 \\
\hline $\mathrm{A} 26$ & 0.029 & 0.61 & N.S. & 0.046 & B49 & 0.032 & 0.89 & N.S. & 0.036 \\
\hline A28 & 0.021 & 0.52 & N.S. & $0.04 I$ & $\mathrm{~B} 60$ & 0.011 & 0.30 & N.S. & 0.035 \\
\hline A32 & 0.039 & 1.16 & N.S. & 0.034 & $\mathrm{~B} \mid 4$ & 0.014 & 0.40 & N.S. & 0.035 \\
\hline $\mathrm{A} 23$ & 0.047 & 1.52 & N.S. & 0.031 & B38 & 0.032 & 1.10 & N.S. & 0.029 \\
\hline A33 & 0.007 & 0.26 & N.S. & 0.027 & B27 & 0.036 & 1.29 & N.S. & 0.028 \\
\hline A 25 & 0.032 & 1.60 & N.S. & 0.020 & B50 & 0.018 & 0.76 & N.S. & 0.023 \\
\hline A3I & 0.011 & 0.67 & N.S. & 0.016 & B65 & 0.039 & 1.74 & N.S. & 0.023 \\
\hline
\end{tabular}

Freq: Frequency n: Total number of alleles in each group OR: Odds ratio p: Significance level N.S.: Not significant

The allele frequencies of the HLA-A and -B antigens in the H63D homozygous group in comparison with the frequencies in the control population are listed in Table 3. Significant associations were found for HLA-A29 and B44. Again, the association of the HLA-A antigen (HLAA29) is stronger than HLA-B44. The frequencies of the HLA-A/B haplotypes are also listed in Table 2, and three HLA-A/B haplotypes (with the same HLA-A antigen, HLAA29) are significantly associated with the H63D mutation: HLA-A29/B44, HLA-A29/B14 and HLA-A29/B62.

From the 17 individuals heterozygous for the S65C mutation, $7(20 \%)$ were HLA-A26 versus $4.6 \%$ found in the control population $(\mathrm{p}=0.02, \mathrm{OR}=5.29)$. No association with HLA-B has been found.

The significant associations did not change if we used a control group of 230 individuals without HFE mutations.

\section{Discussion}

Populations of homozygous individuals for C282Y and H63D are optimal groups to study the HLA haplotypes in which these mutations preferentially appear. To our knowledge, Barton [19] and the present work are the only studies of associations between HFE mutations and HLA antigens and haplotypes in homozygous probands. The paper by Barton and Acton [19] presents haplotype frequencies assessed by family studies where phase could be set; in our paper, the haplotype frequences are estimated because the probands and controls are unrelated individuals. The low frequency of the S65C mutation makes the sampling of homozygous probands difficult and imposes the use of heterozygous individuals for the analysis.

\section{C282Y and HLA}

The strong association between the HLA-A3/B7 haplotype and the $\mathrm{C} 282 \mathrm{Y}$ mutation indicates that this haplotype is the main one associated with this mutation in the Spanish population. However, other haplotypes are also associated: HLA-A3/B62 and HLA-A3/B44. This finding supports the founder hypothesis of Simon et al [5]: the ancestral haplotype where the $\mathrm{C} 282 \mathrm{Y}$ mutation occurred on the ancestral haplotype HLA-A3/B7 and subsequent recombinations involving both HLA-B and HLA-A alleles produced the varied haplotype associations that have been found. Thus, we found many HLA-A/B haplotypes in our C282Y group, but only three HLA-A3 bearing haplotypes are statistically associated with this mutation. The two less frequent haplotypes (HLA-A3/B44 and HLA-A3/ $\mathrm{B} 62$ ) have been observed in other populations in association with $\mathrm{HH}[20,21]$.

In addition, the high frequency of the HLA-A3/B7 haplotype makes other HLA antigens and haplotypes have reduced frequencies in respect to the controls. It is interesting to see that haplotypes with high-frequency in the Spanish population, such as HLA-A30/B18 and HLA-A2/ $\mathrm{B} 51$ are absent in the $\mathrm{C} 282 \mathrm{Y}$ homozygous group (Table 2). These HLA haplotypes are not contaminated by the $\mathrm{C} 282 \mathrm{Y}$ mutation, and up until now, these haplotypes may be considered as protector haplotypes.

\section{H63D and HLA}

Porto et al [3] and Cardoso et al [22] found individual associations between HLA-A29 and non-classical forms of iron overload in linkage disequilibrium with H63D, and a strong linkage disequilibrium between H63D and all 
A29 containing haplotypes assigned in a large population of normal portuguese families.

In the present work we found a strong association between the HLA-A29/B44 haplotype and the H63D mutation. Our finding agrees with the association of HLAA29/B12(44) and hemochromatosis described in the Danish population [21].

H63D and HLA-A29-bearing haplotypes follow a pattern of associations similar to that described for $\mathrm{C} 282 \mathrm{Y}$ and HLA-A3-bearing haplotypes. This promotes speculation that HLA-A29/B44 is the ancestral haplotype from which the H63D mutation emerged, since other HLA-A29 carrying haplotypes are also statistically associated with the mutation (HLA-A29/B14 and HLA-A29/B62, see Table 2), confirming the results reported by Cardoso et al [22] in the normal Portuguese population. Studies in other populations might lend support to whether HLA-A29/B44 is the ancestral haplotype of the H63D mutation, and HLAA29/B14 and HLA-A29/B62 are specific Spanish haplotypes associated with H63D mutation.

\section{C282Y and H63D mutations: which one is older?}

In an attempt to establish the relative age of $\mathrm{C} 282 \mathrm{Y}$ and H63D mutations, we have analysed the geographical distribution, allele frequencies and HLA haplotype associations for each mutation, assuming that the mutations ocurred once and that its age is directly proportional to its geographical spread, its frequency in the population, and the number of HLA haplotypes to which they are linked. On the other hand, a strong association of a particular HFE mutation to a particular HLA haplotype could mean that the mutation arose more recently, since the lower number of ruptures and recombinations of the original haplotype would reflect that a shorter time has passed.

Merryweather-Clarke et al [23] analysed 2978 samples from probands distributed world-wide and showed that the $\mathrm{C} 282 \mathrm{Y}$ mutation was most prevalent in northern European populations and absent from samples of nonEuropean subjects (Africans, Asians, Australasians and Americans). In contrast, the H63D mutation is not restricted to European populations, being found in countries bordering the Mediterranean, in the Middle East and in the Indian subcontinent, and its allele frequency is higher than that of the $\mathrm{C} 282 \mathrm{Y}$ mutation [23]. Our analysis of $\mathrm{C} 282 \mathrm{Y}$ and $\mathrm{H} 63 \mathrm{D}$ homozygous groups yielded a higher number of HLA haplotypes in association with the H63D mutation; and the frequency of HLA-A3/B7 in the C282Y homozygous group is $20 \%$, while the frequency of HLAA29/B44 in the H63D homozygous group is 13\% (see table 2), reflecting that the HLA-A29/B44/H63D haplotype has suffered more recombinations than HLA-A3/B7/
C282Y, and therefore, that HLA-A29/B44/H63D is older [24].

Altogether, these features suggest that the H63D mutation may have occurred earlier than the $\mathrm{C} 282 \mathrm{Y}$ mutation, as has been previously proposed in studies from Italian populations $[25,26]$.

\section{S65C and HLA}

Few studies have been performed on the distribution, frequency and HLA association of the S65C mutation in Europe and other continents. Barton et al [13] described the linkage of the S65C mutation to a HLA-A32 haplotype in hemochromatosis probands from Alabama. Surprisingly, Couto et al [14] found the linkage of S65C (and not H63D) to the HLA-A29/B44 haplotype in a population from the Azores, although only 5 H63D homozygous and 9 S65C heterozygous individuals were studied in that work.

In the present work we find that the $565 \mathrm{C}$ mutation seems to be linked to HLA-A26 in the Spanish population. Further studies in other populations and with more S65Cbearing haplotypes are necessary to shed light on the generation of the S65C mutation.

\section{Conclusions}

We have found that, in the Spanish population, the three main HFE mutations: $\mathrm{C} 282 \mathrm{Y}, \mathrm{H} 63 \mathrm{D}$ and S65C, are in linkage disequilibrium with HLA haplotypes carrying the HLA-A3, -A29 and -A26 alleles, respectively. In addition, the ancestral HLA haplotypes from which $\mathrm{C} 282 \mathrm{Y}$ and H63D mutations were originated are HLA-A3/B7 and HLA-A29/B44, respectively, and H63D is older than C282Y. Further studies in other populations using homozygous individuals for HFE mutations will help to identify the associated ancestral and specific haplotypes.

\section{Competing interests}

The author(s) declare that they have no competing interests.

\section{Authors' contributions}

Authors AP and PM conceived the study, contributed to proband characterisation, performed statistical comparisons and edited the manuscript. Authors EM, MJR, MJC, DO, MGB and LG contributed at different times to the characterisation of probands and HLA typing.

\section{Acknowledgements}

We would like to thank the people who worked with the samples for several years: Belén Suárez and Mario González. Also, to Estela Paz-Artal for the critical review of the manuscript. 


\section{References}

I. Feder JN, Gnirke A, Thomas W, Tsuchihashi Z, Ruddy DA, Basava A, Dormishian F, Domingo R Jr, Ellis MC, Fullan A, Hinton LM, Jones NL, Kimmel BE, Kronmal GS, Lauer P, Lee VK, Loeb DB, Mapa FA, McClelland E, Meyer NC, Mintier GA, Moeller N, Moore T, Morikang E, Prass CE, Quintana L, Starnes SM, Schatzman RC, Brunke KJ, Drayna DT, Risch NJ, Bacon BR, Wolff RK: A novel MHC class Ilike gene is mutated in patients with hereditary hemochromatosis. Nat Genet 1996, I 3:399-408.

2. Candore G, Mantovani V, Balistreri CR, Lio D, Colonna-Romano G, Cerreta V, Carru C, Deiana L, Pes G, Menardi G, Perotti L, Miotti V, Bevilacqua E, Amoroso A, Caruso C: Frequency of the HFE gene mutations in five Italian populations. Blood Cells Mol Dis 2002, 29(3):267-73.

3. Porto G, Alves H, Rodrigues P, Cabeda JM, Portal C, Ruivo A, Justio B, Wolff R, De Sousa M: Major histocompatibility complex class I associations in iron overload: evidence for a new link between the HFE H63D mutation, HLA-A29, and non-classical forms of hemochromatosis. Immunogenetics 1998, 47:404-4I0.

4. Mura C, Raguenes O, Ferec C: HFE mutations in 7 I I hemochro-

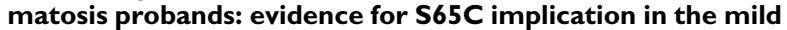
form of hemochromatosis. Blood 1999, 93:2502-2505.

5. Simon M, Le Mignon L, Fauchet R, Yaouanq J, David V, Edan G, Bourel $M$ : A study of 609 HLA haplotypes marking for the hemochromatosis gene: (I) mapping of the gene near the HLA-A locus and characters required to define a homozygous population and (2) hypothesis concerning the underlying cause of hemochromatosis-HLA association. Am J Hum Genet 1987, 4I:89-105.

6. Lloyd DA, Adams P, Sinclair NR, Stiller CR, Valberg LS: Histocompatibility antigens as markers of abnormal iron metabolism in idiopathic hemochromatosis. Can Med Assoc J 1978, I | 9: 1051-1056

7. Dyrszka H, Eberhardt G, Eckert G: The distribution of HLA-antigens in German patients with idiopathic hemochromatosis. Klin Wochenschr 1979, 57:529-531.

8. Bomeford A, Eddleston AL, Kennedy LA, Batchelor JR, Williams R: Histocompatibility antigens as markers of abnormal iron metabolism in patients with idiopathic hemochromatosis and their relatives. Lancet 1977, I:327-329.

9. MacCarthy D, Fitzgerald GA, O'Connel LG, Waters JM, Watt DW, Stevens FM, McCarthy CF, Drury MI: Histocompatibility antigens and hemochromatosis in Ireland. Ir J Med Sci I 979, I:28I-282.

10. Simon M, Bourel M, Fauchet R, Genetet B: Association of HLA-A3 and HLA-BI4 antigens with idiopathic hemochromatosis. Gut 1976, I 7:332-334.

II. Piperno A, Fargion S, Panaiotopoulos N, Del Nido E, Taddei MT, Fiorelli G: Idiopathic hemochromatosis and HLA antigens in Italy: A3 BW35 HLA haplotype a marker for idiopathic hemochromatosis gene in north east regions? J Clin Pathol I 996, 39:126-128.

12. De Juan MD, Reta A, Castiella A, Pozueta J, Prada A, Cuadrado E: HFE gene mutations analysis in Basque hereditary hemochromatosis patients and controls. Eur J Hum Genet 200I, 9:96I-964.

13. Barton JC, Sawada-Hirai R, Rothenberg BE, Acton RT: Two novel missense mutations of the HFE gene (I I 05T and G93R) and identification of the S65C mutation in Alabama hemochromatosis probands. Blood Cells Mol Dis 1999, 25:147-I55.

14. Couto AR, Peixoto MJ, Garrett F, Laranjeira F, Cipriano T, Armas JB: Linkage disequilibrium between S65C HFE mutation and HLA A29-B44 haplotype in Terceira Island, Azores. Hum Immunol 2003, 64:625-628.

15. Schneider S, Roessli D, Excoffier L: Arlequin 2000: A software for population genetics data analysis. Volume. Genetics and Biometry Laboratory, University of Geneva, Switzerland; 2000:-.

16. Dempster A, Laird N, Rubin D: Maximum likelihood estimation from incomplete data via the EM algorithm. J Roy Statist Soc 1997, 39: 1-38.

17. Svejgaard A, Ryder LP: HLA and disease association: Detecting the strongest association. Tissue Antigens 1994, 43: 18-27.

18. Woolf $B$ : On estimating the relation between blood groups and disease. Ann Hum Genet 1995, 19:251-253.

19. Barton JC, Acton RT: HLA-A and -B alleles and haplotypes in hemochromatosis probands with HFE C282Y homozygosity in central Alabama. BMC Medical Genetics 2002, 3:9-I7.
20. Ritter B, Safwenbergr J, Olson KS: HLA markers of the hemochromatosis gene in Sweden. Hum Genet 1984, 68:62-66.

21. Milman N, Graudal N, Nielsen LS, Fender K: An HLA study in 74 Danish hemochromatosis patients and in $2 \mathrm{I}$ of their families. Clin Genet 1992, 4 I:6- II.

22. Cardoso CS, Alves H, Mascarenhas M, Goncalves R, Oliveira P, Rodrigues $\mathrm{P}$, Cruz E, De Sousa M, Porto G: Co-selection of the H63D mutation and the HLA-A29 allele: a new paradigm of linkage disequilibrium? Immunogenetics 2002, 53: I002-1008.

23. Merryweather-Clarke AT, Pointon JJ, Shearman JD, Robson KJH: Global prevalence of putative hemochromatosis mutations. J Med Genet 1997, 34:275-278.

24. Ajioka RS, Jorde LB, Gruen JR, Yu P, Dimitrova D, Barrow J, Radisky $E$, Edwards CQ, Griffen LM, Kushner JP: Haplotype analysis of hemochromatosis: evaluation of different linkage-disequilibrium approaches and evolution of disease chromosomes. Am J Hum Genet 1997, 60(6): |439-|447.

25. Lio D, Balistreri CR, Colonna-Romano, Motta M, Franceschi C, Malaguarnera M, Candore G, Caruso C: Association between the MHC class I gene HFE polymorphisms and longevity: a study in the Sicilian population. Genes Immunity 2002, 3:20-24.

26. Candore G, Mantovani V, Balistreri CR, Lio D, Colonna-Romano G, Carreta V, Carru C, Deiana L, Pes G, Menardi G, Perotti L, Miotti V, Bevilacqua E, Amoroso A, Caruso C: Frequency of the HFE gene mutations in five Italian populations. Blood Cells Mol Dis 2002, 29:267-273.

\section{Pre-publication history}

The pre-publication history for this paper can be accessed here:

http://www.biomedcentral.com/1471-2350/5/25/prepub

Publish with BioMed Central and every scientist can read your work free of charge

"BioMed Central will be the most significant development for disseminating the results of biomedical research in our lifetime. "

Sir Paul Nurse, Cancer Research UK

Your research papers will be:

- available free of charge to the entire biomedical community

- peer reviewed and published immediately upon acceptance

- cited in PubMed and archived on PubMed Central

- yours - you keep the copyright

BioMedcentral 